\title{
Nas entranhas da América periférica: reflexões sobre a busca de um pensar mais próprio
}

\section{In the bowels of peripheral America: reflections on the search for a more authentic thought}

Maria Fernanda Ceccon Vomero ${ }^{1}$ 


\section{Resumo}

O presente artigo busca questionar a permanência de uma epistemologia extrínseca nos argumentos que têm constituído o pensamento político da chamada América Latina e acabam por naturalizar uma suposta superioridade do saber ocidental sobre os demais. Partimos de uma breve análise de leituras a respeito de $A$ Tempestade, de William Shakespeare, e propomos o deslocamento do eixo analítico para as entranhas do continente por meio de Caranguejo Overdrive, peça da carioca Aquela Cia. de Teatro. Reivindicamos, assim, a presença do corpo e de suas políticas na argumentação sobre a porção centro-sul da América.

Palavras-chave: A Tempestade; Caranguejo Overdrive; América Latina; ocidente; pensamento político
The present work intends to question the permanence of an extrinsic epistemology in the arguments that have constituted the political thought of the so-called Latin America and end up naturalizing a supposed superiority of Western knowledge over the others. We begin with a brief analysis of the William Shakespeare's The Tempest, and propose the displacement of the analytical axis into the bowels of the continent by examining Caranguejo Overdrive, a play by Aquela Cia. de Teatro, from Rio de Janeiro. We thus claim the presence of the body and its policies in the argumentation concerning the center-south portion of America.

Keywords: The Tempest; Caranguejo Overdrive; Latin America; west; political thought

E-ISSN: 2358.6958

${ }^{1}$ Doutoranda do Programa de Pós-Graduação em Artes Cênicas da Universidade de São Paulo (PPGAC - USP). Jornalista autônoma, performer e provocadora cênica na Companhia de Teatro Heliópolis. mafevomero@gmail.com 


\section{A Tempestade, de Shakespeare, e o olhar de fora}

Entre as peças do repertório da companhia gaúcha Tribo de Atuadores Ói Nóis Aqui Traveiz - que celebrou quarenta anos de existência em 2018 -, está Caliban A tempestade de Augusto Boal, uma encenação para teatro de rua com 15 atores e atrizes estreada em março de 2017. A obra foi resultado do Projeto Caliban - Apontamentos sobre O Teatro de Nuestra América, contemplado pelo programa Rumos Itaú Cultural 2015-2016, que previu o processo de criação do espetáculo, a realização de seminários com o tema "Caliban e o teatro latino-americano", turnês nacionais e a apresentação da peça em Cuba, coroando uma acurada pesquisa sobre a figura de Caliban, personagem da peça A Tempestade, de William Shakespeare, transformado em símbolo da identidade latino-americana por escritores e intelectuais do continente, como o martinicano Aimé Césaire (2011) e o cubano Roberto Fernández Retamar (2004), para citar alguns.

Augusto Boal, diretor e dramaturgo brasileiro, criador do Teatro do Oprimido, partiu do texto de Shakespeare para questionar o colonialismo europeu e o neocolonialismo estadunidense sobre o continente americano. Última peça do dramaturgo inglês, provavelmente escrita e encenada pela primeira vez em 1611, época das explorações marítimas europeias, A Tempestade original narra uma história de disputas e dominação. Próspero, duque de Milão, é destituído do poder por seu irmão Antônio, com apoio do rei de Nápoles, Alonso, e do irmão deste, Sebastião. Graças ao conselheiro Gonçalo, em vez de morto, acaba exilado em uma ilha com sua filha Miranda e seus livros. Próspero se apossa das terras, expulsa Sicorax, antiga governante da ilha, descrita como "bruxa maldita", e escraviza os demais habitantes - Caliban, o selvagem e disforme filho de Sicorax, e o espírito Ariel -, por meio da magia aprendida com os livros. O primeiro se mantém insubmisso e agressivo; o segundo opta pela subserviência como modo de obter a liberdade ansiada.

O título da peça remete à tormenta provocada por Próspero, com apoio de Ariel, que leva as embarcações onde se encontram Antônio, Alonso, Sebastião, o amigo Gonçalo e o príncipe Ferdinando, de Nápoles, a naufragarem justamente na ilha. Deste modo, Próspero reencontra e confronta seus desafetos, além de promover o romance entre Miranda e Ferdinando, numa sagaz estratégia política. Uma fala de Ariel a Próspero sugere que a ilha se situe no Caribe - "O navio do rei está no porto, no golfo em que uma vez me convocaste para buscar orvalho das Bermudas tempestuosas" -, embora haja também remissão a algum ponto entre Nápoles (Europa) e Túnis (África).

Segundo Bernardo Ricupero (2014), ainda que elementos do texto de Shakespeare possam ser relacionados à colonização do continente americano, foi no final do século XVIII, coincidindo com a emergência do romantismo - movimento que permitiu a construção social da ideia de nação -, que a ilha e seus habitantes passaram a ser identificados por estudiosos e acadêmicos com o Novo Mundo. Múltiplas leituras sobre $A$ Tempestade têm sido realizadas desde então, respondendo a interpelações ideológicas distintas. Em muitas delas, Próspero passa a ser visto como usurpador, à imagem e semelhança dos colonizadores europeus. 
Na transição do século XIX ao XX, como aponta Ricupero (2016), os personagens de Shakespeare aportaram definitivamente, via França, na região que passou a ser chamada de América Latina², graças às abordagens de escritores ligados ao modernismo. Inicialmente, Ariel é identificado com a elite intelectual latina e Caliban, com os Estados Unidos (cf. Groussac, 1898; Darío, 1998), ou, respectivamente, com aristocracia/espiritualismo e com democracia/materialismo (Rodó, 1993). Sob uma perspectiva marxista, como a do argentino Aníbal Ponce, em Humanismo burgués y humanismo proletario (1938), os personagens são ressignificados: Ariel, "gênio do ar, sem ataduras com a vida", é associado ao humanismo burguês (o intelectual ideologicamente ligado ao opressor, que deplora o proletariado), e Caliban, às "massas sofridas".

Novas abordagens despontaram ao longo da década de 1960 - as dos barbadenses George Lamming e Kamau Brathwaite e dos citados Césaire e Retamar - , já numa perspectiva anticolonialista, relacionando Caliban aos povos latino-americanos (a despeito de todas as contradições inerentes a essa generalização). A versão brasileira de A Tempestade surgiu na década seguinte. Em 1974, Augusto Boal, perseguido pela ditadura civil-militar do Brasil e exilado em Buenos Aires, adaptou a obra de Shakespeare, mas não conseguiu apresentá-la na Argentina devido à crescente repressão naquele país. A Tempestade de Boal só foi encenada pela primeira vez em 1981, dirigida por José Luiz Ribeiro, no Rio de Janeiro. Na ilha situada no "Caribe tropical", Caliban é ciente da opressão que sofre; tem, inclusive, consciência de classe - não à-toa constam, de seu vocabulário, termos como "patrão", "operário", "direito" e "revolução". Dá seus primeiros passos como personagem-sujeito, experimentando alguma autonomia de pensamento. Boal cria um Caliban disposto a desafiar o "colonialismo capitalista" que se alicerça, em grande medida, no domínio do capital cultural. Contudo, isso ainda não é suficiente: as relações de poder não se rompem ao final.

Na releitura da Tribo de Atuadores Ói Nóis Aqui Traveiz, as contradições da figura de Caliban e o contexto de luta de classes se tornam mais evidenciados; os personagens incorporam menções, implícitas ou explícitas, ao momento político conturbado pelo qual passam Brasil e outros países da América do Sul (o processo de criação da peça se deu ao longo de 2016, ano da destituição da presidenta Dilma Rousseff). Durante a tempestade, por exemplo, os marinheiros decidem entrar em greve. "Como seus filhos em terra morrem de fome, eles preferem morrer afogados a voltar para casa", afirma o capitão. Caliban está no título do espetáculo no intento de indicar seu protagonismo; trata-se de um posicionamento político do grupo teatral. De acordo com os "atuadores" (como se denominam os artistas-ativistas da companhia), a opção por apresentar a obra em espaço público era inevitável. "Agora, mais do que

\footnotetext{
${ }^{2}$ Segundo Martinez (2016), a denominação "América Latina" foi empregada pela primeira vez e simultaneamente pelos autores Francisco Bilbao e José María Torres Caicedo em 1856, seguindo a ideia anterior de uma latinidade que unia Portugal, Espanha, França e Itália e que, por sua vez, poderia sugerir o vínculo entre as ex-colônias de três desses países no continente americano. Embora não seja o tema deste artigo, América Latina nos parece uma denominação insuficiente e equivocada, especialmente por carregar consigo rastros do ideário de uma Europa colonialista.
}

${ }^{3}$ A respeito desse tema, ver: Patrícia Santos. 0 teatro sob a tempestade: uma leitura crítica de A tempestade, de Augusto Boal. Sala Preta, 18 (1), p. $85-97,2018$. https://doi.org/10.11606/issn.2238-3867.v18i1p85-97 
nunca, é imprescindível que estejamos ocupando o espaço da rua. Vê o retrocesso que ocorre no Brasil em termos de legislação, os temas em que estamos regredindo, a privatização do espaço público", afirmou a atuadora Tânia Farias em entrevista 4 .

O espetáculo estrutura-se em treze cenas, que se intercalam com igual número de canções em coro - uma delas, o Canto da Sicorax, é entoado na língua do povo indígena Kaingang, presente na porção sudeste-sul do Brasil, remetendo aos habitantes originários do continente. Embora Ariel seja interpretado por um trio de atores, o personagem em si parece menos relevante na montagem dos atuadores que no texto de Boal. O programa da peça o apresenta como um "artista alienado, mescla de escravo e mercenário a serviço da ordem constituída". Caliban, contudo, é uma figura de destaque e, quando entra em cena, vem acompanhado por um coro de Calibans - opção estética relevante, pois permite leituras múltiplas sobre a articulação entre a emancipação individual e a luta coletiva.

A montagem da Tribo de Atuadores confirma a potência e a polissemia do texto de Shakespeare, suas inteligência e sensibilidade na elaboração dos personagens e também a atualidade de seus temas, quatro séculos depois. Como destacou Barbara Heliodora (2008, p.8),

Se for necessário apresentar motivos pelos quais se deva ler Shakespeare, hoje em dia, todos eles poderão ser encontrados em sua capacidade de investigar e compreender a fundo os processos do ser humano, tanto em sua condição de indivíduo como de integrante de um grupo social.

No entanto, é interessante notar como Próspero continua a ser o eixo dramatúrgico estruturante, mesmo quando apresentado de modo crítico em montagens mais recentes, como a dos atuadores gaúchos. Ainda que a encenação abra espaço para que os marginalizados sejam representados e tenham voz, isso não significa necessariamente ruptura com o que Aníbal Quijano (1992) chama de "colonialidade do poder" - ou seja, uma ampla matriz de controle "sobre os modos de conhecer, de produzir conhecimento, de produzir perspectivas, imagens e sistemas de imagens, símbolos, modos de significação" (op. cit., p. 12), que permaneceu no imaginário dos povos colonizados mesmo depois dos processos de independência e descolonização histórica. Afinal, Próspero - europeu, branco, nobre, símbolo do que se entende por "civilização" e "Ocidente" - ainda aparece, de maneira dissimulada ou naturalizada, como articulador da ordem e detentor do saber autorizado, contra o qual Caliban se opõe, legitimando-o como referência.

Assim, os temas do pensamento político latino-americano que se alimentam de A Tempestade, de William Shakespeare, admitem como ponto de partida a epistemologia dada, alheia, "do colonizador", para ensaiar uma crítica dessa mesma epistemologia. No entanto, a análise da interação entre Próspero, Ariel e Caliban não consegue criar categorias do conhecimento que contemplem, de modo dialógico ou em pé de

\footnotetext{
${ }^{4}$ Fábio Prikladnicki. Ói Nóis Aqui Traveiz estreia releitura de Shakespeare por Augusto Boal. Gauchazh, Porto Alegre, 9 mar. 2017. Espetáculos. Disponível em: https:// gauchazh.clicrbs.com.br/cultura-e-lazer/espetaculos/noticia/2017/03/oi-nois-aqui-traveiz-estreia-releitura-de-shakespeare-por-augusto-boal-9744460.html - Acesso em: 15 ago. 2018.
} 
igualdade, os saberes, as produções culturais e o modus vivendi das populações nativas do continente americano, que ainda resistem a processos genocidas perpetrados ou apoiados pelos Estados. Tampouco tal análise admite o profundo impacto que a escravidão - levada adiante por Prósperos e Alonsos - provocou, ao longo de séculos, nos corpos e nas mentalidades da América, repercutindo inegavelmente na organização político-social e econômica atual dos países que a compõem.

Caliban, nas versões de Aimé Césaire e Augusto Boal, experimenta o início de um profícuo processo de individuação - aqui, usamos o termo segundo Paolo Virno $(2013)^{5}$ - , o que lhe permite emancipar-se ao menos da imagem que lhe é/foi determinada. Diz Caliban a Próspero, em Césaire (2011, p. 146) ${ }^{6}$ :

E você me mentiu tanto, me mentiu sobre o mundo, mentiu sobre mim mesmo, que acabou por me impor uma imagem de mim mesmo: um subdesenvolvido, como você diz, um subcapaz, é assim como você me obrigou a me ver, e eu odeio essa imagem! E ela é falsa! Mas agora o conheço, velho câncer, e me conheço também!

Tal emancipação, porém, não foi suficiente para romper os mecanismos hegemônicos que a trama de Shakespeare ilumina. Em Boal, Caliban permanece aprisionado pela opressão do sistema capitalista; em Césaire, a conquista da liberdade insere-se no plano individual, sem a destruição ou recriação da máquina "mágica" de exclusões, marginalizações, silenciamentos e invisibilizações criada por Próspero, em contínua operação na atualidade por meio do necropoder (Mbembe, 2011) e suas práticas de morte tão disseminadas no continente. A matriz colonial de poder, em si, não foi questionada; ao contrário, continua sendo reafirmada na medida em que é a referência contra a qual se opõe Caliban. Tampouco há deslocamento epistêmico: a opressão dos corpos continua em segundo plano.

Muitos intelectuais da porção centro-sul do continente americano, contudo, preferem insistir na agenda da modernidade/colonialidade e usar Caliban para argumentar contra o populismo, o patrimonialismo e a violência social que atrasariam o desenvolvimento das ditas nações latinas, ainda tão distantes da sonhada integração ao Ocidente, sem pôr em xeque essas ideias todas. Parecem também defender tal agenda sem questionar a herança de Próspero e sem levar em consideração o árduo e incompleto processo emancipatório de Caliban, o que demandaria muito mais que referências esparsas a temas como identidade nacional, contribuições ameríndias ou tradições culturais afro-americanas. "Ao propor Caliban como nosso símbolo, me dou conta de que tampouco é inteiramente nosso, também é uma elaboração estranha, ainda que esta vez o seja a partir de nossas concretas realidades", afirma Roberto Fernández Retamar (2004, p. 36)7. Seria preciso, então, transcender a epistemologia

\footnotetext{
${ }^{5}$ Em linhas gerais, ponto de chegada do processo de configuração de uma singularidade única a partir dos muitos que configuram uma multidão.

${ }^{6}$ No original: "Et tu m'as tellement menti, menti sur le monde, menti sur moi-même, que tu as fini par m'imposer une image de moi-même: Un sous-développé, comme tu dis, un sous-capable, voilà comment tu m'as obligé à me voir, et cette image, je la hais! Et elle est fausse! Mais maintenant, je te connais, vieux cancer, et je me connais aussi!". (Tradução nossa)

7 "Al proponer a Caliban como nuestro símbolo, me doy cuenta de que tampoco es enteramente nuestro, también es una elaboración extraña, aunque esta vez lo sea a partir de nuestras concretas realidades". (Tradução nossa)
} 
alheia para criar uma própria; elaborar um pensamento político que inclua outros saberes e perspectivas, especialmente os dos irrepresentados e irrepresentáveis (Grüner, 2003).

Antes de prosseguirmos, vale ressaltar que as reflexões do presente artigo têm, como disparadores iniciais, as teses de Walter Benjamin em Sobre o Conceito de História (2012), especialmente a VII (a tarefa de escovar a história a contrapelo) e a IX (o anjo da história). Nesta última, inclusive, há uma menção à tempestade que impele o anjo irresistivelmente para o futuro, enquanto ele - talvez como o Caliban revisto por Césaire - gostaria de deter-se para acordar os mortos (Sicorax?) e juntar os destroços (a ilha pós-Próspero?). "Essa tempestade é o que chamamos progresso" (Benjamin, op. cit., p. 226).

Entre as considerações que Michael Löwy (2005) faz a respeito das teses de Walter Benjamin, consta uma referência à invasão ibérica ao continente americano:

\begin{abstract}
A conquista ibérica, esse primeiro capitulo da história colonial europeia, 'transformou o mundo recém-conquistado em uma câmara de torturas', escreve Benjamin. As ações da 'soldadesca hispânica' criaram uma nova configuração espiritual (Geistesverfassung) que 'não podemos representar sem horror (Grauen)'. Como toda colonização, a do novo continente tinha suas razões econômicas - os imensos tesouros de prata e ouro das Américas - mas os teólogos oficiais trataram de justificá-Ia com argumentos jurídico-religiosos: 'A América é um bem sem proprietários; a submissão é uma condição da missão; intervir contra os sacrifícios humanos dos mexicanos é um dever cristão'. (Löwy, op. cit., p. 10)
\end{abstract}

A esse trecho, soma-se uma anedota que, a nosso ver, revela por que outras premissas deveriam ser consideradas como matrizes para o pensamento político latino-americano. Segundo Löwy, enquanto Estado, Igreja e iniciativas privadas preparavam, em 1992, no México, comemorações para o 5 centenário da "descoberta das Américas", reforçando a empatia com os heróis oficiais, os integrantes do Exército Zapatista de Libertação Nacional comandaram um ato de reparação simbólica: a destruição da estátua de Diego de Mazariega, o conquistador, no centro de São Cristóbal de las Casas, em Chiapas, por uma multidão de indígenas que desceu das montanhas. Os monumentos concretos da conquista colonial, como estátuas e edificações, são muito mais fáceis de reconhecer que os paradigmas, categorias e formulações teóricas que até hoje condicionam a subalternidade teórica e política de saberes diversos, divergentes ou marginais em relação ao pensamento ocidental.

\title{
Manguezais, charcos e pântanos: entranhas de um pensamento do sul
}

Em busca de reativar pontos de partida não-hegemônicos para a formulação de novas abordagens políticas sobre a porção centro-sul do continente americano, propomos uma breve imersão pela dramaturgia e a encenação de Caranguejo Overdrive, peça da carioca Aquela Cia. de Teatro, estreada em 2015 e apresentada em diversas cidades brasileiras - em algumas delas, em mais de uma temporada - e em festivais no exterior. Escrita por Pedro Kosovski e dirigida por Marco André Nunes, Caranguejo Overdrive surgiu do desejo da companhia de trabalhar com temas presentes na 
obra do médico, geógrafo e intelectual pernambucano Josué de Castro (1908-1974) e com as batidas e os ecos do movimento cultural Manguebeat, idealizado no Recife, no início dos anos 1990, por um grupo de artistas - entre eles, o compositor e cantor pernambucano Chico Science (1966-1997). O Manguebeat combina elementos da cultura local, como o maracatu rural e o coco, e influências pop, a exemplo do rock e do hip-hop. O manifesto que originou o movimento intitulou-se "Caranguejos com cérebro", em referência a um dos principais habitantes da lama dos manguezais.

Entre os livros de Josué de Castro que mais influenciaram a pesquisa da Aquela Cia., estão os basilares Geografia da fome, o dilema brasileiro: pão ou aço (1946), no qual o autor examina a questão da fome no país, relacionando-a à exploração monocultora e latifundiária que perseverava desde os tempos coloniais, e Geopolítica da fome: Ensaio sobre os Problemas de Alimentação e de População do Mundo (1951), em que argumenta que a problemática da fome no planeta estaria muito mais vinculada à distribuição desigual de alimentos, pois parte da população não disporia de meios econômicos para adquiri-los, que à produção insuficiente deles. Em outros escritos, Castro já assinalava: "O subdesenvolvimento é um produto ou um subproduto do desenvolvimento, uma derivação inevitável da exploração econômica colonial ou neocolonial, que continua se exercendo sobre diversas regiões do planeta"8. Josué de Castro, que presidiu o conselho executivo da Organização das Nações Unidas para Agricultura e Alimentação (FAO-ONU) entre 1952 e 1956 e tinha sido nomeado embaixador brasileiro na ONU em 1962, perdeu seus direitos políticos com o golpe civil-militar em 1964 e foi proibido de voltar ao Brasil.

A ficção Homens e caranguejos (1967), um olhar sobre a vida miserável dos jovens catadores de caranguejo no mangue recifense, quase transformados em crustáceos para sobreviver naquele hábitat, também foi fundamental para disparar o processo de pesquisa da peça. O romance oferece inspiração concreta para a elaboração do personagem Cosme, protagonista de Caranguejo Overdrive, o homem pobre e esfomeado que catava caranguejo no mangue do Rio de Janeiro e foi recrutado pelo exército brasileiro para lutar na Guerra do Paraguai (1864-1870) - conflito armado que uniu Brasil, Uruguai e Argentina contra o país governado por Solano López e pode ter matado até $\mathbf{4 0 0}$ mil pessoas no total, entre civis e militares, em razão dos combates ou de epidemias resultantes.

Em um de seus rompantes-desabafos-manifestos-monólogos, Cosme afirma (Kosovski, 2016, p. 33):

Lembro que fui soldado na Guerra do Paraguai, sob o comando do coronel Manuel Pedro Drago, eu era um menino e fui forçado a me alistar como um voluntário da pátria, sim, no mangue eu já ouvia falar dos cavaleiros da miséria e suas armaduras de barro, mas na guerra éramos perseguidos por projéteis e não por muriçocas, eu fui sequestrado pelo Exército Brasileiro, eu e tantos outros, índios, negros, escravizados, pobres e crianças, os excluídos da pátria, voluntariamente forçados a lutar por interesses que não eram os nossos, ideias que jamais chegamos a debater ou pensar [...].

\footnotetext{
${ }^{8}$ Em Anna Maria Castro (org.). Fome: um tema proibido. Últimos escritos de Josué de Castro. Rio de Janeiro: Civilização Brasileira, 2003.
} 
Cosme sobrevive à guerra e, ao voltar ao Rio de Janeiro, perturbado e marcado emocional e fisicamente pelos horrores vividos, encontra uma cidade em acelerada transformação. A fome permanece como consequência dos "males sociológicos", como diria Josué de Castro. A escolha de situar Cosme no mangue carioca em vez do recifense permitiu ao dramaturgo Kosovski e aos demais artistas de Aquela Cia. traçarem um panorama das mudanças urbanísticas pelas quais passava a então capital do Império; o Mangal de São Diogo, que se estendia da Praça Onze (antigo Rocio Pequeno) até a Baía da Guanabara, foi totalmente aterrado a fim de expandir o tecido urbano da cidade na direção oeste e promover a circulação e o saneamento da região. Assim, em 1860 foi inaugurado o Canal do Mangue, empreendimento de Irineu Evangelista de Sousa, o Barão de Mauá, cujas obras ficaram a cargo do engenheiro inglês William Gilbert Ginty. Em 1876, efetuaram-se novas intervenções para melhorias e embelezamento.

Se A Tempestade, de William Shakespeare, foi criada como texto dramatúrgico independente, o texto de Caranguejo Overdrive foi concebido paralelamente às improvisações dos atores e à encenação proposta pelo diretor. Obviamente que a dramaturgia, agora publicada em livro, pode ser montada por diretores e intérpretes diferentes, como aconteceu com A Tempestade. Contudo, sua tessitura reflete o modelo de criação teatral conhecida como processo colaborativo, que preza pela horizontalidade nas relações entre artistas-criadores do espetáculo teatral; assim, rompe-se com a autoria única, seja do dramaturgo, seja do diretor. No processo colaborativo, que se tornou bastante presente entre o teatro de grupo na cena brasileira a partir dos anos 1990, o dramaturgo continua responsável pela ordenação textual e o diretor, pela organização da cena, contudo ambos não se sobrepõem aos demais artistas (intérpretes, músicos, iluminador etc.).

Como isso se reflete, então, em nossa análise? Não podemos tomar apenas o texto como fonte de estudo, mas considerar também a encenação - que convoca a presença e a experiência da investigadora e desafia o pensamento (usualmente trancado na torre de marfim do distanciamento acadêmico) a acolher outros modos de saber. Caranguejo Overdrive acontece numa instalação cênica não muito grande, em retângulo, que comporta um tanque raso de areia ao centro e, ocupando cada canto, uma gaiola com alguns caranguejos vivos (substituídos por pedras em cidades onde não se permite o uso de animais em cena), um flip-chart, um aquário de vidro com lama e um microfone no pedestal. Esses ambientes são iluminados segundo o desenrolar da trama. A banda fica posicionada numa das laterais, geralmente sob a sombra. Os atores, quando deixam a cena, não saem da instalação; ocupam cadeiras que circundam o retângulo. O público fica à frente e nas laterais, em almofadas no chão, cadeiras ou arquibancadas baixas. Quando assistimos à peça, no teatro da Caixa Cultural São Paulo, éramos pouco mais de 80 espectadores.

A trama não é linear, outra marca do teatro contemporâneo. Somos logo apresentados a Cosme, o protagonista, caranguejo que um dia foi homem. Ele anuncia que não sabe bem quem fala, porque pode ser a fome - o apetite manifesto - que faz surgir as palavras. Essa fome também o transformou em caranguejo e o devolveu a um mangue mítico, à lama primordial, onde se misturam seres vivos e excrementos, 
fontes de vida e restos. Em seguida, uma cientista que estuda crustáceos e um contador de histórias partilham a cena e revezam-se em suas falas sobre o caranguejo, uma mais erudita, outra mais popular, misturando relatos da biologia e das tradições brasileiras. Volta Cosme, interrogado por um oficial do exército em seu retorno ao Brasil depois da guerra. Na sequência, narra suas memórias da barbárie que presenciou no campo de batalha. O ponto de vista é sempre do ex-catador de caranguejo de mangue, do homem iletrado, esfomeado. No retorno, Cosme não reconhece mais o Rio de Janeiro, busca o mangue. Encontra uma prostituta paraguaia, raptada por um militar brasileiro, responsável por matar sua família durante a guerra e depois abandoná-la na área das obras de aterramento. E, num dos pontos altos da encenação, é essa prostituta quem conta a história do Brasil, do fim do Império aos dias de hoje (chega ao impeachment de Dilma Rousseff e à Operação Lava Jato), em portunhol.

Tudo é permeado pelas batidas dançantes do Manguebeat. Findo o relato da paraguaia, um escravo das obras de aterramento apresenta a história do Mangal de São Diogo e os interesses escusos que rondam o dispendioso projeto de construção do canal. No outro canto da cena, três atores, então, se põem a conversar com os caranguejos na gaiola. Os crustáceos sentem fome; querem comer o quê? Transgênicos, comida sem glúten, orgânicos, macrobióticos, pão, pão, queijo, queijo? As perguntas simples dos atores despertam digressões na pesquisadora: como, num país que se encontra entre os maiores produtores de alimento, a fome e a subnutrição ainda gritam entre a população? Por que países com território menor conseguem usar menos agrotóxicos e água, produzir mais alimentos e distribuí-los com mais amplitude e igualdade?

Cosme, então, tem mais um rompante; homem-elétrico, coberto por pequenas luzes, em alta voltagem, ele divaga sobre as mudanças em prol do progresso na Cidade Nova9 . Em seguida, morto de fome, vai pedir emprego nas obras. Vira escravo em troca de alimento, cavando, cavando, cavando. Por fim, o caranguejo se despede do que restou de Cosme em si. Cosme morreu escravo, famélico, perturbado pelas lembranças horríveis da guerra, e foi jogado no canal, virando alimento dos crustáceos sobreviventes e resistentes. Em cena, vemos um homem coberto de lama dos pés à cabeça, imóvel numa posição que se assemelha à de um caranguejo. Vem uma tempestade. A transformação está completa: Cosme é, a partir daquele momento, um caranguejo.

Embora associemos Cosme ao ator Matheus Macena, que inicia a peça deitado no tanque de areia, revelando aos poucos sua transformação em crustáceo por meio de espasmos, parte de seus relatos são enunciados pelos demais atores, reforçando a polifonia do texto. Quem é Cosme, na verdade? O brasileiro pobre, escravo liberto, negro ou indígena marginalizado, involuntário "voluntário da pátria", oprimido pela constante busca de modernização e progresso? O sul-americano igualmente pobre, famélico, explorado pelos ideais capitalistas neoliberais e pelas epistemologias alheias? O indivíduo da porção centro-sul do continente americano que não

${ }^{9}$ Lembramos que a peça foi escrita para celebrar os 450 anos do Rio de Janeiro (1565-2015), no contexto de processos de gentrificação e remoção populacional a fim de viabilizar a construção de grandes empreendimentos - ou seja, "disputa de territórios da cidade para a realização dos Jogos Olímpicos de 2016" (Kosovski, 2016, p. 21) 
às elites, que não participa das decisões políticas, que é mera rubrica em processos ditos modernizantes, fadado à posição infinita de objeto da história? Todos os subalternos dessas pátrias ibero-americanas que se constituíram à revelia dos povos, mas à imagem e semelhança de suas aristocracias e oligarquias? Ou Cosme seria, na verdade, uma mulher - oculta, silenciada e esquecida na história do continente até o século XX? Quem seria Cosme? Houve, há ou haveria espaço para Cosme no pensamento político latino-americano?

Nossa análise sobre Caranguejo Overdrive reivindica o papel do corpo na teoria política, na reflexão sobre a organização do Estado, na discussão sobre políticas públicas, na compreensão da ideia de nação e identidade nacional. Não se pode mais negar a politicidade do corpo, dos corpos. Fome, exploração física, escravidão, genocídios, estupros, tortura, valas comuns ("a guerra é branca", diz Cosme), tudo isso vem sendo ignorado por boa parte dos intelectuais que se dedicam a estudar a formação das mentalidades na porção centro-sul do continente americano. Como se as tais mentalidades não fossem afetadas por aquilo que afeta os corpos; talvez os corpos protegidos por questões de gênero, raça, classe e acesso aos bens culturais, aqueles vinculados às produções intelectuais legitimadas, estejam resguardados das políticas de morte e, por isso, as vidas nuas (Agamben, 2014) entrem apenas como menções ou exemplos isolados em suas teorias.

Caranguejo Overdrive situa sua trama no século XIX, coincidentemente o período em que muitos intelectuais do continente começaram a formular argumentos a respeito de uma possível identidade latino-americana. Contudo, a ideologia operante situava o modelo, os parâmetros, o começo dos começos na Europa. Hoje, sob o que se considera o ideal ocidental, incorpora também o exemplo dos Estados Unidos. Ao vencedor, já dizia o Quincas Borba de Machado de Assis, as batatas. O espólio dos vencidos, os bens culturais, os monumentos, os hinos, os heróis, a História, o ideário do Estado perfeito e a receita do desenvolvimento.

Aos vencidos, a lama, o atraso, o subdesenvolvimento, rastros pré-modernos, o anacronismo, processos incompletos, instituições falhas, a periferia, o sul do mapa. Idiomas que não servem no meio acadêmico internacional, misticismo rançoso, caudilhismos, populismos, ditaduras sangrentas, movimentos messiânicos, guerrilhas desorganizadas, miséria, fome, desigualdade social, replicações culturais. Mangues insalubres, charcos, primitivismo, animismo. Bruxas, pajés, Exus e Xangôs. A barbárie. Ora, faz-se necessário rever concepções sobre uma suposta carência de modernização e racionalidade nas sociedades latino-americanas como explicação plausível para a fragilidade de suas democracias e a desigualdade social. Naturalizar a hierarquização das sociedades, tomando as nações ocidentais como exemplares, não estaria turvando a argumentação?

\section{Um exercício de imaginação política}

O início da história da ilha não se dá com a chegada de Próspero (seja ele Cristóvão Colombo, Américo Vespúcio, Pedro Álvares Cabral etc.), como sugerem muitas leituras feitas sobre $A$ Tempestade, reafirmando o ponto de vista do invasor (que narra 
sua aparição como feito heroico e inevitável). Se esse dado não é problematizado, aceita-se tacitamente que Próspero se torne dono do passado e do presente da América. E mais: acata-se que o Próspero, como modelo (= Ocidente, na atualidade), seja o parâmetro de ordem e de progresso, de manutenção do poder e de legitimação do conhecimento. Daí a importância política de examinarmos a América Latina desde o ponto de vista de suas entranhas, levando em conta a materialidade das vidas e as políticas que atuam sobre os corpos, sem deixar de reconhecer que suas nações igualmente sofrem as dinâmicas do capitalismo financeiro neoliberal.

Não pretendemos, neste artigo, desmerecer as contribuições ao pensamento político latino-americano que fazem uso de um arcabouço teórico, argumentativo e bibliográfico eminentemente alheio (ou seja, de fora, não latino-americano). Nossa provocação baseia-se na crítica à ampla influência de um certo discurso hegemônico sobre o mundo, que tem normalizado e normatizado a exclusão de saberes produzidos em contextos diferentes, a negação da politicidade dos corpos (ignorando, por consequência, os efeitos de genocídios, escravidões e torturas cometidos no além-mar) e o descrédito de outros modos de viver e de interagir com a natureza, fazendo uso de opacas hierarquias morais. Por isso mesmo, talvez a denominação América Latina ainda soe artificial, porque pressupõe similaridades pensadas desde fora - e não de dentro. Não seria América Latina uma categoria alheia às vivências dessa região do continente, baseada em relações de dominação sociais, econômicas, políticas, culturais?

Chamemos Cosme de volta, ouçamos seu ponto de vista, atentemos à voz e à fome de Cosme, à vertigem elétrica que percorre seu corpo e explode em significados. Cosme, o caranguejo que foi homem, personagem do mangue. Em seu texto no prefácio do livro Caranguejo Overdrive, o diretor da peça, Marcos André Nunes, comenta que a equipe precisou aprender a lidar com os caranguejos vivos usados no espetáculo. Os artistas eram habilidosos e delicados no cuidado com os crustáceos, mas, ainda assim, alguns acabavam morrendo. Depois de pesquisar, descobriram que erravam ao isolar os bichos, pois "os caranguejos não podem ficar sozinhos. A solidão torna o caranguejo letárgico e inativo, paralisando-o e levando-o à morte. Caranguejos precisam de outros caranguejos" (Kosovski, 2016, p. 15).

Como articular um pensamento político que contemple as nações do continente partindo de outras formas de sociabilidade, que não as paradigmáticas? Outras vozes precisam ser ouvidas nesse debate. Aqui trazemos algumas reflexões do destacado pensador e líder político brasileiro Ailton Krenak, representante de uma tribo originária da região do Vale do Rio Doce, os krenak ${ }^{10}$, em Minas Gerais. Ele afirma, por exemplo, "que a perspectiva de América Latina é uma perspectiva da cabeça dos brancos, não é uma perspectiva da cultura e da cabeça dos índios" (2015, p. 152). Os grupos étnicos originários mantêm viva a memória de sua origem - trajetórias que remontam a 10 mil, 20 mil anos -, mas se colocam desde o lugar onde estabelecem relação com o universo, uma concepção espiritual da existência, sem determinações de ordem geopolítica, ideológica, estratégica ou moderna. "A história", diz Krenak

${ }^{10}$ Ver https://pib.socioambiental.org/pt/Povo:Krenak - Acesso em: 15 ago. 2018. 
(op. cit, p. 153), "não começou de jeito nenhum em 1500 com a chegada dos brancos".

Sobre articulações com outros grupos do continente, ele comenta:

\begin{abstract}
A solidariedade indígena está fundada em princípios que não são os princípios do confronto; não são os princípios da revolução burguesa, da revolução moderna, são povos tribais. Eu costumo dizer que a sociedades indígenas são sociedades de alianças. Essas alianças se estabelecem pelo casamento, por comungarem o mesmo espaço de caça, de colheita, de pesca; por terem cantos, expressões e ritos que se assemelham. Essa solidariedade está marcada profundamente por uma expectativa com relação a vida, com relação ao entendimento de mundo, mas ela não supõe isso que modernamente chamam de solidariedade política. É diferente, é uma solidariedade que está vinculada muito mais a uma origem, a uma memória da origem do povo. (Krenak, 2015, p. 151)
\end{abstract}

Ou seja, trata-se de uma experiência de convívio com profundo respeito pela territorialidade do outro, "como elemento fundador também de sua identidade, de sua cultura e do seu sentido de humanidade" (idem, p. 162). Os princípios que regem os modos de pensar e de existir dos povos nativos não são os mesmos estudados pelas Ciências Políticas tradicionais ou aqueles disseminados pelo capitalismo e por suas teorias de legitimação. Na aula pública ${ }^{11}$ dada durante o ato Abril Indígena, em 20 de abril de 2016, na Cinelândia, Rio de Janeiro, e intitulada Os Involuntários da Pátria, o antropólogo Eduardo Viveiros de Castro diz que ser brasileiro (e, com as devidas adaptações, poderia ser argentino, peruano, boliviano, cubano etc.):

é pensar e agir e se considerar (e talvez ser considerado) como 'cidadão', isto é, como uma pessoa definida, registrada, vigiada, controlada, assistida - em suma, pesada, contada e medida por um Estado-nação territorial, o 'Brasil'. Ser brasileiro é ser (ou dever-ser) cidadão, em outras palavras, súdito de um Estado soberano, isto é, transcendente. Essa condição de súdito (um dos eufemismos de súdito é 'sujeito [de direitos]') não tem absolutamente nada a ver com a relação indígena vital, originária, com a terra, com o lugar em que se vive e de onde se tira seu sustento, onde se faz a vida junto com seus parentes e amigos.

Nas duas últimas décadas, a América do Sul assistiu à ascensão de princípios éticos e filosóficos que se pautam no acúmulo das experiências indígenas e desafiam os paradigmas civilizacionais da modernidade e do capitalismo - em especial, a ideia de progresso. Tanto o Sumac Kawsay (em quéchua, Buen Vivir), no Equador, quanto o Suma Qamaña (em aymara, El Buen Convivir), na Bolívia, se constituíram em matrizes para novos projetos políticos, ainda em construção e obviamente em disputa: projetos baseados no modo de vida comunitário, na distribuição igualitária de recursos, no respeito à diversidade, na complementaridade (equilíbrio entre coletividade e individualidade), entre outros tópicos. Como compreender o que poderia ser a América, as Américas, desde tais abordagens?

Pensar sobre o continente americano também implica pensar na população negra de origem africana, nos descendentes de mulheres e homens tirados à força de seu território nativo e trazidos como escravas e escravos ao tal Novo Mundo. "Todo o

${ }^{11}$ Ver: https://www.academia.edu/25144372/OS_INVOLUNTÁRIOS_DA_PÁTRIA . Acesso em: 15 ago. 2018. 
relato histórico sobre a emergência do terror moderno precisa ter em conta a escravidão, que pode ser considerada uma das primeiras manifestações da biopolítica" (Mbembe, 2011, p. 31). A condição do escravo implica uma tripla perda: a do lar, a dos direitos ao seu corpo e a do status político, deixando-o submetido à dominação absoluta e à morte social.

A população negra é alvo até hoje de um genocídio paulatino, conduzido por Estados que buscam o embranquecimento. "Ser e viver como negro não é uma peripécia comum na vida ocidental", escreveu Abdias do Nascimento (1961, pp. 9-10). No rol de valores culturais europeus/estadunidenses/ocidentais, que ainda predomina nas Américas, não existe - fora da esfera anedótica - espaço para os saberes negros, para a cidadania negra e muito menos para a emancipação política negra. O racismo se mostra explícito nas políticas de morte e dissimulado nos discursos oficiais, acadêmicos, culturais. Democracia, liberalismo, direita, esquerda e até mesmo socialismo parecem ser, na prática, ideais brancos (e masculinos).

Nesse intricado caminho reflexivo que propusemos, em meio ao mangue, aos caranguejos e às tempestades, nos deparamos também com a frustração de não nos reconhecermos numa ideia de América Latina que veio sendo elaborada, ao menos, até o fim do século XX. Tomar como base que o fato de portugueses, espanhóis e franceses terem colonizado a maior parte do continente é o que une as nações do centro-sul americano soa insuficiente, tanto quanto elaborar análises a partir das ditas heranças, com o apagamento de tudo o que não é português, espanhol e francês. Como apontou Retamar (2004, p. 22),

[...] nosotros, los latinoamericanos y caribeños, seguimos con nuestros idiomas de colonizadores. Son las linguas francas capaces de ir más allá de las fronteras que no logran atravesar las lenguas aborígenes ni los créoles. Ahora mismo, que estoy discutiendo con estos colonizadores, ¿de qué otra manera puedo hacerlo, sino en una de sus lenguas, que es ya también nuestra lengua, y con tantos de sus instrumentos conceptuales, que también son ya nuestros instrumentos conceptuales?

Sentimo-nos, assim, eletrocutadas pelos raios da tempestade do futuro, aquela mesma que insiste em carregar o anjo benjaminiano. Cosme morre, mas na utopia poética e política de Caranguejo Overdrive ele se transforma em caranguejo para voltar ao mangue mítico, ao mangue-palimpsesto, e reiniciar o ciclo de vida. Talvez seja um profícuo exercício de imaginação política esquecer a tal América Latina e passar a recriar outra América, com suas centenas de idiomas e narrativas, desde suas próprias entranhas, de seus corpos, de seus pântanos, charcos, mangues - e gentes.

\section{Referências}

AGAMBEN, Giorgio. Homo Sacer. O Poder Soberano e a Vida Nua I. $2^{\underline{a}}$ edição. Belo Horizonte: Editora UFMG, 2014.

BENJAMIN, Walter. Obras escolhidas I. Magia e técnica, arte e política: ensaios sobre 
literatura e história da cultura. 8ª edição. São Paulo: Brasiliense, 2012.

BOAL, Augusto. A tempestade, 1974. [Versão digitalizada cedida à pesquisadora]

CALIBAN - A tempestade de Augusto Boal, 2015 (adaptação Tribo de Atuadores Ói Nóis Aqui Traveiz). [Versão digitalizada cedida à pesquisadora]

CÉSAIRE, Aimé. Una tempestad. Buenos Aires: El 8vo. loco, 2011.

DARíO, Rubén. El triunfo de Calibán. In: Revista Iberoamericana, v. 64, n. 184-185, p. 451-455, 1998.

FERNANDEZ RETAMAR, Roberto. Calibán. In: Todo Calibán. Buenos Aires, CLACSO, 2004, p. 19-81.

GROUSSAC, Paul. Discurso del sr. P. Groussac. In: España y Estados Unidos. Buenos Aires: Compañia Sud-Americana de Billetes de Banco, 1898, p. 31-56.

GRÜNER, Eduardo. Del experimento al laboratorio, y regreso. Argentina o el conflicto de las representaciones. In: Sociedad, Buenos Aires: Facultad de Ciencias Sociales/ UBA, n. 20/21, p. 27-54, 2003.

HELIODORA, Barbara. Por que ler Shakespeare. Globo: São Paulo, 2008.

KOSOVSKI, Pedro. Caranguejo Overdrive. Rio de Janeiro: Cobogó, 2016.

KRENAK, Ailton e COHN, Sérgio. Encontros: Ailton Krenak. Rio de Janeiro: Azougue, 2015.

LÖWY, Michel. Walter Benjamin - Um Aviso de Incêndio. Uma leitura das teses Sobre o conceito de história. São Paulo: Boitempo, 2005.

MARTÍNEZ, Rubén Torres. Sobre el concepto de América Latina. Invención francesa? In: Cahiers d'études romanes, n. 32, p. 89-98, 2016. DOI: 10.4000/etudesromanes.5141

MBEMBE, Achille. Necropolítica. Barcelona: Melusina, 2011.

NASCIMENTO, Abdias. Dramas para negros e prólogo para brancos. Rio de Janeiro: Teatro Experimental do Negro, 1961.

QUIJANO, Aníbal. Colonialidad y modernidad/racionalidad. In: Perú Indígena (Pcnllndig), v. 13, n. 29, pp. 11-20, 1992. 
RICUPERO, Bernardo. A Tempestade e a América. In: Lua Nova. São Paulo, n. 93, p. 11-31, dez. 2014. http://dx.doi.org/10.1590/S0102-64452014000300002.

. Ariel na América: Viagens de uma Ideia. In: Intersecções. Rio de Janeiro, v. 18, n. 2, p. 372-407, dez. 2016. https://doi.org/10.12957/ irei.2016.26574 .

RODÓ, José E. Ariel. In: Ariel y Motivos de Proteo. Caracas: Biblioteca Ayacucho, 1993, p. 1-56.

VIRNO, Paolo. Gramática da multidão: para uma análise das formas de vida contemporâneas. São Paulo: Annablume, 2013.

Recebido em: 22/08/2018

Aprovado em: 26/04/2019 